\title{
Oxford Bibliographies
}

\author{
Your Best Research Starts Here
}

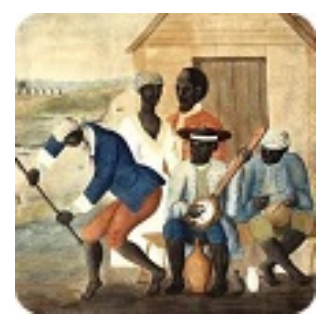

\section{Social Science and Civil Rights}

Ben Keppel

LAST MODIFIED: 28 JUNE 2016

DOI: $10.1093 / O B O / 9780190280024-0014$

\section{Introduction}

Considered from within the prism of American history, the terms social science and civil rights, when combined, have a particular meaning bound up in the nation's continuing struggle over whether to treat a certain native-born group as full and equal members of American society. More than one hundred and fifty years after the end of the explicit constitutional sanction of chattel slavery, a force field of hostility toward this group (whether identified as "colored," Negro, or "African American") remains intact, and it is often the framework through which many other persons classified as "nonwhite" are treated. American social science, at its foundation, most often gave an official imprimatur to the exclusion and denigration of people of color. Its "founding fathers" strove to construct a systematic method for understanding human conduct modeled on the natural sciences. These particular experts came to their task with the preexisting assumption that a racial hierarchy-white over black-was the natural order of things. We start here from the premise that race is just as deliberately human and political an invention as are the concepts civil rights and social science. Race has been the most consequential (and dangerous) of these terms because it has been used to render as natural patterns of inequality between people created by human beings themselves. Second, social scientists and their disciplines do not stand apart from the forces that they study; rather, their interests and conclusions are also decisively influenced by them. This neither diminishes nor discredits the continuing enterprise of social science; it serves that work best by reminding us of its difficulty and complexity. Finally, we best capture the full range of social science thinking when a net is cast broad enough to include those rigorous analysts who come from outside the core social sciences (sociology, anthropology, economics) to embrace salient contributions in literature, law, philosophy, and a vast literature of social observation and critique that is an indispensable part of modern life. When a variety of figures without academic degrees in a "social science" are treated here as legitimate contributors to it, it is because we must not forget the broadly philosophical and humanistic origins of social science. The relationship between social science and civil rights over a history spanning two hundred years follows closely the evolution of how Americans and their institutions have answered the first question of any human society: who belongs?

\section{A View from the Present}

The early 21 st century is a paradoxical time in which to be living and thinking formally about relationships between social science and race. Since the 1980s, the discipline of African American studies has become more firmly anchored in the intellectual establishment of American letters. The labor of Yale University historian John Blassingame has insured that the words and ideas of Frederick Douglass have been preserved in a comprehensive and easily accessible collection (Douglass 1979-1992). So too, the leadership of Darlene Clark Hine, Henry Lewis Gates Jr., Evelyn Brooks-Higginbotham, and Colin Palmer have bequeathed to us some basic reference tools that heretofore had not been available at such a high level of quality (Hine 2005, Gates and Higginbotham 2008, Palmer 2006). At the same time, Americans were reminded of the force field of suspicion and resistance against which African Americans must present themselves when Professor Gates was arrested in the summer of 2009 as he sought to enter his own Cambridge, Massachusetts home after returning from a vacation (Goodnough 2009). As we consider the particular public and private burdens imposed upon African American intellectuals today, John Hope Franklin's memoir, Mirror to America (Franklin 2005), gives us an invaluable and intimate sense of how personal is the cost.

\section{Douglass, Frederick A. The Frederick Douglass Papers. Edited by John W. Blassingame. New Haven, CT: Yale University Press,}


1979-1992.

Of special interest to readers of this essay will be Volumes 1-5 of Series 1, Speeches, Debates and Interviews.

Franklin, John Hope. Mirror to America: The Autobiography of John Hope Franklin. New York: Farrar Strauss and Giroux, 2005.

This memoir is especially valuable for Franklin's account of the pressures he faced while writing the first African-American history textbook that would find its way from 1947 onward into the college classrooms of historically white institutions.

Gates, Henry Louis, Jr., and Evelyn Brooks Higginbotham, eds. African-American National Biography. 8 vols. New York: Oxford University Press, 2008.

This essential reference, buttressed by a frequently revised online site, contains nearly 5,000 entries that include not only biographies of significant figures, but also authoritative essays on key movements. In addition to featuring the work of recognized academic authorities, the editors reached out to exceptional high school scholars for innovative essays. Available online for purchase.

Goodnough, Abby. “Harvard Professor Jailed; Officer Accused of Bias.” New York Times, 20 July 2009.

Coverage by the New York Times of the arrest of Gates. It is also a fitting beginning to any discussion of social science and civil rights.

Hine, Darlene Clark, ed. Black Women in America. 2d ed. 3 vols. New York: Oxford University Press, 2005.

See Hine's candid autobiographical introduction in the first edition, which describes the origins of this project in 1980 at the insistence of Shirley Herd, president of the Indianapolis section of the National Council of Negro Women.

Palmer, Colin A., ed. Encyclopedia of African-American Culture and History: The Black Experience in the Americas. 2 d ed. 6 vols. Detroit: Macmillan Reference, 2006.

First published in 1996, this resource consists of 1,300 articles on various aspects of African American culture from 1619 to the present. The first edition, published in 1996, focused on African American history, whereas the second edition also contains essays and other supporting materials on the African American experience across the Americas.

\section{Understanding the Force Field of White Supremacy in American Culture}

There is no "race gene" in human beings that naturally either attracts or repels entire groups of people toward or away from one another. Since World War II, classicist Frank M. Snowden Jr.'s explorations of interactions between Greeks and other peoples demonstrate that notions of race and racism did not exist in ancient times (Snowden 1991). A work of corollary research, Patterson 1982 has found no neat and natural link between the development of slavery and racial ideology-most societies have some form of slavery in their past, but this does not necessarily lead to a racial ideology. American historians, inspired by the Civil Rights movement, first identified race and "racism in action by documenting the negative attributes that many European colonialists assigned to "blackness" (Jordan 1968). Sociologists Michal Omi and Howard Winant have focused on "racial formation" as a stable yet fluid ideological process that often keeps former hierarchies in place even as specific racial categories (and the population they represent) prove to be remarkably fluid. Racial formation is centered in the state itself (Omi and Winant 1986). Higginbotham 1978 illustrates this process when the author charts the creation of slavery as a life-time category to permanently mark off certain groups from political or social membership in the polity. Painter 2010 adds to this more subtle understanding of race by examining how leading American thinkers and institutions from the 19th century onward have conceived and elaborated a durable identity of American "whiteness" linked in its first iteration to an almost biological affinity with "Britishness." Painter conceives of "whiteness" as a distinctive category of identity that seems remarkably able to preserve a "black/white" duality, even as American society itself has become more diverse. Looking at developments from the end of the Civil War forward, Foner 1988 demonstrates how the gravity exerted by racialized thinking made Reconstruction following the Civil War brief, 
limited, and temporary. Even after a second period of reconstruction in the 1960s, African Americans (and many others officially categorized as "colored") find themselves part of a system that often regards them as lesser citizens and lesser people (Higginbotham 1996). In fact, three hundred years removed from the first formation of race in American law and social custom, a racial regime remains resiliently in place even as its scope and terms are contested (Omi and Winant 2012).

Foner, Eric. Reconstruction: America's Unfinished Revolution, 1863-1877. New York: Harper and Row, 1988.

Foner's survey of post-Civil War Reconstruction synthesizes the most important social and political historical scholarship on this subject. $\mathrm{He}$ is particularly adept at featuring both the brief but notable political successes as well as the failure to alter social and economic relations, leaving that for later generations to address.

Higginbotham, A. Leon, Jr. In the Matter of Color: Race and the American Legal Process: The Colonial Period. New York: Oxford University Press, 1978.

By his own estimate, Higginbotham has read every published appellate case or statute in American law on the subject of slavery between 1630 and 1865, and this volume is the impressively detailed result of that labor.

Higginbotham, A. Leon, Jr. Shades of Freedom: Racial Politics and the Presumptions of the American Legal Process. New York: Oxford University Press, 1996.

In this successor to Higginbotham 1978, Higginbotham charts the evolution of the "precept of black inferiority and white superiority" in American law from 1619 to the 1990s. His appendix, "Ten Precepts of American Slavery Jurisprudence," is essential reading.

Jordan, Winthrop D. White over Black: American Attitudes toward the Negro, 1550-1812. Chapel Hill: University of North Carolina Press, 1968.

Perhaps the single most ambitious historical monograph of American racial attitudes completed in the midst of the Civil Rights movement. Jordan digs deep to locate the roots of a white supremacist national culture in the European and American evaluation of the African as a libidinous and uncivilized heathen.

Omi, Michael, and Howard Winant. Racial Formation in the United States: From the 1960s to the 1980s. New York: Kegan Paul, 1986.

Though focused on interpreting the reformation and reordering of racial ideologies since the Civil Rights movement, this short book also provides a critique of how the process of racial formation was integral to the American polity from the very beginning and how it was essential to shaping social science in the United States.

Omi, Michael, and Howard Winant. "Racial Formation Rules: Continuity, Instability and Change." In Racial Formation in the TwentyFirst Century. Edited by Daniel Martinez HoSang, Oneka LaBennett, and Laura Pulido, 302-331. Berkeley: University of California Press, 2012.

The authors discuss the factors that led them to reappraise the social science of racial and ethnic relations in the early and mid-1980s.

Painter, Nell Irvin. The History of White People. New York: W. W. Norton, 2010.

A rigorous analysis of how leading Americans, often drawing upon contemporaneous European intellectual currents, viewed the overlapping themes of race and culture. Painter's discussion of the changing role of the census in American life since 1800 is especially noteworthy. 
Patterson, Orlando. Slavery and Social Death: A Comparative Study. Cambridge, MA: Harvard University Press, 1982.

Heretofore the scholarly discussion of slavery was organized around the comparison of differences between slave systems. Patterson focuses on the unifying importance of domination as superseding ethnic and racial differences in many cases. Patterson further argues that, without slavery, humans would have no conception of freedom. A schematic survey, specialists admire its ambition while criticizing overgeneralizations.

\section{Snowden, Frank M., Jr. Before Color Prejudice: The Ancient View of Blacks. Cambridge, MA: Harvard University Press, 1991.}

Snowden argues that "The ancient world did not make color the focus of irrational sentiments ... The ancients ... made ethnocentric judgments of other societies; ... Yet nothing comparable to ... virulent color prejudice ... existed in the ancient world" (p. 63).

\section{From Moral Philosophy to Social Science in 19th-Century America}

Social science has its origins in the effort of moral philosophers to apply the laws and methods of the natural and biological sciences to human society. As this statement implies, systematic social observation has a history longer than the social sciences themselves. With particular reference to the United States, African Americans have been pursuing, like other people, systematic knowledge of society for a very long time (Holloway and Keppel 2007). The social science discourse assumed the inevitable progressive trajectory of human history (Porter 2003): Ross 1991 argues that this same enterprise was underway in the United States before the social sciences were formally established in the later 19th century, complete with an American conviction of the exceptionalism of American institutions and a history confined to the lives of a white upper class steeped in millennial thinking. The belief in the inevitability of human progress and in the superiority of the West extended across American society to include African Americans. Bay 2000 draws upon an impressive array of sources within the African American culture of the 19th century to demonstrate the ways in which the drive to systematically understand human life ordered black thought toward the fundamental equality and humanity of all peoples, even as some were closer to enlightenment than others. In the years before the institutionalization of the social sciences, Frederick Douglass was the single most important African American representative of the drive toward a "science of society." Douglass's last public speech, "The Lessons of the Hour" delivered in 1894 and published as a pamphlet in the same year, exemplifies his skills as a modern social analyst (Douglass 1894). Martin 1984 demonstrates how Douglass drew upon a Western discourse rooted in the physical and biological sciences to argue for human unity across racial and culture differences while also sharing in the assumption that the European West was at the top of human learning. Ernest 2011, a study of the black convention movement, confirms that Douglass was intellectually representative of organized free people of color in the United States. Henry Lewis Gates Jr. sees Douglass as the "representative man" of this community to the world (Gates 1988). Brooks-Higginbotham 1993 extends our understanding of this movement by focusing on the political activism of the women of the National Baptist Convention. We cannot leave this subject without noting an essential tendency evident here: the search for objective knowledge often starts with a commitment to challenge and change the existing order of things.

\section{Bay, Mia. The White Image in the Black Mind: African-American Ideas about White People, 1830-1925. New York: Oxford University Press, 2000.}

Among other topics, this exceptionally wide-ranging study of African American thinking in the 19th century provides compelling evidence that African Americans, even if they were not invited to be founders of American social science, were nonetheless sophisticated contributors to this public work.

\section{Brooks-Higginbotham. Righteous Discontent: The Women's Movement in the Black Baptist Church, 1880-1920. Cambridge, MA: Harvard University Press, 1993.}

By focusing on the activities of women within the Black Baptist Convention, this study provides one of the first scholarly treatments of how African American women entered upon a public sphere from which they were excluded by both race and gender. 
Douglass, Frederick. The Lessons of the Hour, Address Delivered in the Metropolitan A. M. E. Church, Washington, D.C. on Tuesday, January 9, 1894, in Which He Discusses the Various Aspects of So-Called but Mis-called Negro Problem. Baltimore: Press of Thomas Evans, 1894.

Douglass devoted his last formal public speech to a detailed analysis of the cultural assumptions, psychological roots, economic interest, and political motivations for the lynching of African Americans in the generation after the end of the Civil War. This address is a model of social observation and a worthy precursor to the cultural studies movement of the 21 st century.

Ernest, John. A Nation-within-a- Nation: Organizing in African-American Communities before the Civil War. Chicago: Ivan R. Dee, 2011.

Ernest's intellectual history of the antebellum black convention movement demonstrates the ubiquity of the effort to counter the tenets of white supremacy. It also demonstrates the degree to which African Americans understood the cultural complexities and difficulties inherent in the aspiration to be both a person of color and an American.

Gates, Henry Lewis, Jr. "The Trope of the New Negro and the Reconstruction of the Image of the Black." Representations 24 (1988): 29-55.

In an important early contribution, Gates uses Douglass here to explore the use of the terms "new Negro" and "Reconstruction" to introduce students of late-19th-century American culture to idea that Reconstruction had a deep cultural as well political resonance and meaning to these Americans.

Holloway, Jonathan Scott, and Ben Keppel. Black Scholars on the Line: Race, Social Science and American Thought in the Twentieth Century. Notre Dame, IN: Notre Dame University Press, 2007.

This anthology collects the social scientific thinking of African Americans from the establishment of the American Negro Academy in 1897 through the 1970s. This collection serves as an excellent companion reading to the synthetic reinterpretation in Ross 1991.

Martin, Waldo F. The Mind of Frederick Douglass. Chapel Hill: University of North Carolina Press, 1984.

Martin skillfully situates Douglass in the transatlantic intellectual community formed by leading intellectuals in Britain and the United States.

Porter, Theodore M. "Genres and Objects of Social Inquiry from the Enlightenment to 1890." In The Cambridge History of Science. Vol. 7, The Modern Social Sciences. Edited by Theodore M. Porter and Dorothy Ross, 1-40. Cambridge, UK: Cambridge University Press, 2003.

Porter surveys intellectual currents across continental Europe from the Enlightenment (and its culminating event, the French Revolution) to the end of the 19 th century.

Ross, Dorothy. The Origins of American Social Science. New York: Cambridge University Press, 1991.

The key organizing theme of this essential interpretive history is the primacy among the founders of the American social sciences of a belief in the social and political exceptionalism of their country. By the end of the 19th century, this faith is shaken but not destroyed by the turmoil of industrialism.

\section{The Chicago School as the First Capital of American Social Science}


If Washington, DC, is the undisputed capital of government and politics in the United States and New York City its equally influential capital of culture and commerce, the city of Chicago was, from the late 19th century to the end of World War II, the capital of American sociology. During these years, the city of Chicago served as a center of social change on a massive scale, as immigrants from southern and central Europe arrived to work in its industries. In the early 20th century a migration of African Americans from the rural South to take industrial jobs in Chicago also transformed the social and political landscape of both the city and the nation as a whole. To this mix, we must add the University of Chicago. With the support of the Rockefeller family, the University of Chicago became the first capital of social science in the United States, with the field of sociology being the first among equals.

\section{Robert E. Park and the Chicago School of Sociology}

Robert E. Park, a journalist who did not begin his formal career as a professor of sociology at the University of Chicago until he was nearly fifty years old, is the scholar most closely associated with the founding of "intergroup," or "race relations," at the University of Chicago. His interest in this field of study was nurtured especially by his years of work as a speech writer and intellectual adviser to Booker T. Washington, an African American educator who founded the Tuskegee Institute and became the most powerful African American leader of his time. In his thinking about race and culture, Park did not endorse the concept of a racial hierarchy rooted in the biological superiority of Europeans; rather, he believed humans were separated by the primitiveness or the cosmopolitanism of their respective cultures (Mathews 1977, Lyman 1992). Park's extensive world travels as well as his intensive study of immigrant communities in Chicago led him to become especially interested in studying the dynamics of cultural contact between peoples of different cultures. This interest compelled him, in turn, to focus special attention on the "marginal man," the migrant who lives in two worlds, never becoming fully at home in either (Park 1950). Goldberg 2012 argues that Park's thinking was influenced by W. E. B. Du Bois's idea of "double consciousness" to explain the complexity of African American identity. The term marginal man no longer guides writing on race, but it has become important in analysis of gender relations (Goldberg 2012, Du Bois 2008).

\section{Du Bois, W. E. B. The Souls of Black Folk. E-book 408, Project Gutenberg, 2008.}

Originally published in 1903. See "Of Our Spiritual Strivings" (pp. 1-8), in which Du Bois considers what it feels like to "be a problem" and explores whether it is possible for the "Negro" in America to be an "American." He argues that the marginal status of the African American enables him to view American society with a special acuity.

\section{Goldberg, Chad Alan. "Robert Park's Marginal Man: The Career of a Concept in American Sociology." Laboratorium Review of Social Research 2 (2012): 199-217.}

Park's thinking was especially influenced by W. E. B. Du Bois's writing on the "double consciousness" among African Americans. Park's concept remains important in the sociology of gender.

\section{Lyman, M. Stanford. Militarism, Imperialism, and Racial Accommodation: An Analysis and Interpretation of the Early Writings of Robert E. Park. Fayetteville: University of Arkansas Press, 1992.}

Consists of the early professional writing and correspondence by Park from before his formal entry into sociology. Of special interest are memos on African American life written by Park for Washington as well as some correspondence between them. See also Stanford's biographical essay on Park.

\section{Mathews, Fred H. Quest for an American Sociology: Robert E. Park and the Chicago School. Montreal: McGill-Queen's University} Press, 1977.

Though nearly forty years old, this volume remains the definitive biographical study of Robert Park, especially valuable for its detailed discussion of his place in the history of American sociology. 
This volume brings together Robert Park's most important writings on the "ecology of intergroup relations in the United States." Two articles reprinted here are particularly important: "The Nature of Race Relations" (1939) and "Human Migration and the Marginal Man" (1928); includes an introductory autobiographical essay by Park.

\section{Model Studies from within the Chicago School}

Although Robert Park wrote about American race relations, the sustained application of his cultural model ultimately rested in other hands. Johnson 1934 provides one of the most detailed studies of the way in which the power relationships of domination begun in slavery held firm sixty years after the formal end of the "peculiar institution." At a time when alleged intellectual superiority of whites (as measured by the first generations of standardized IQ tests) was taken as conclusive evidence of the genetic basis of white racial superiority, Johnson's subtle and tactful analysis suggested that culture, not genetics, explained the difference. Johnson's pioneering efforts led with the presentation of large amounts of data from exhaustive and detailed fieldwork and was far more muted in its refutations of racialist and racist arguments than later generations would find acceptable (Robbins 1996). St. Clair Drake and Horace R. Cayton Jr.'s Black Metropolis tests Park's sense of the "ecology" of urban life on the home ground of Chicago. Drake and Cayton 1945 documents the strength of the boundaries that kept African Americans confined to the cramped "kitchenettes" of Chicago's South Side, and the authors detail the hardships that resulted. At the same time, they also provide evidence of the cosmopolitan changes brought out in this "marginal man" as a result of steadier and higher paying employment. In making this point, Drake and Cayton echo the work of E. Franklin Frazier, who also argued that whatever social "disorganization" handicapped black Americans would be reduced over time by the benefits of greater economic and social opportunity (Frazier 1966, Platt 1991). According to Peretz 2004, the work of these authors still stands in highlighting this section of Chicago as an exemplary community that illuminates an unusual variety of people and forces at work. It is less well known that the field research was funded primarily by the New Deal Works Progress Administration, which enabled Drake and Cayton to hire a racially mixed team of more than 150 field workers who fanned out across the South Side gathering date and interviewing residents. Though Black Metropolis is exemplary of Park's research model, the faculty member most closely associated with the project was W. Lloyd Warner, another important intellectual architect of Chicago School sociology (see Peretz 2004).

\section{Drake, St. Clair, and Horace R. Cayton Jr. Black Metropolis: A Study of Negro Life in a Northern City. New York: Harcourt Brace,} 1945.

The best application of Chicago school methodology to the study of African American life in a major American city. Although two expanded (two volume) editions were published in 1962 and in 1970, the original best captures the style of sociology practiced before World War II.

Frazier, E. Franklin. The Negro Family in the United States. Rev. ed. Foreword by Nathan Glazer. Chicago: University of Chicago Press, 1966.

Like Johnson, Frazier finds that the economic and social relations of slavery continue to "disorganize" African American life. Also like Johnson, Frazier suggests that improvements in economic and social opportunities would overcome these. The foreword by Nathan Glazer conveys how this text has been invoked in contemporary debates about continuing inequality.

\section{Johnson, Charles S. Shadow of the Plantation. Chicago: University of Chicago Press, 1934.}

A landmark community study of how the economic relations of slavery continued to structure the lives of rural blacks sixty years after the enactment of the Thirteenth Amendment, intended by its framers to end slavery in the United States.

\section{Peretz, Henri. "The Making of Black Metropolis." ANNALS of the American Academy of Political and Social Science 595 (September 2004): 168-175.}

Peretz emphasizes the importance of the New Deal Works Progress Administration in assembling a large biracial team of skilled researchers. Although publishing the findings was not originally contemplated, the postwar interest in race (and a foreword by novelist Richard Wright) helped this study find an exceptionally wide audience. 


\section{Platt, Anthony. E. Franklin Frazier Reconsidered. New Brunswick, NJ: Rutgers University Press, 1991.}

This important revisionist interpretation argues that E. Franklin Frazier's thinking on the black family was distorted by the sensationalistic, sloppy, and selective appropriation of it by later sociologists seeking to explain the persistence of "disorganization" in the black family one hundred years after the end of slavery. May also be downloaded through EBSCO website.

\section{Robbins, Richard. Sidelines Activist: Charles S. Johnson and the Struggle for Civil Rights. Jackson: University Press of Mississippi, 1996.}

An excellent study of a social scientist who valued his reputation as a "safe" voice in the councils of American philanthropy and social science.

\section{Gunnar Myrdal and the Dilemma of American Social Science}

Walter A. Jackson helps us understand how international events led to a change in official thinking on race. The coming of World War II and its accompanying actions of a race-conscious variety of fascism was key to the decision of Frederick Keppel of the Carnegie Corporation to launch a comprehensive study of American "race relations" by a certified outsider to American society (Swedish economist Gunnar Myrdal) at the helm (Jackson 1994). To this point, Watkins 2001 finds, the American social science establishment was, like the society that produced it, rigidly segregated by race, with deserving individual scholars allowed to migrate briefly to elite universities for training with the expectation that they would return to the segregated institutions that trained "their people" for "service to the race." This was the mission defined for black scholars and the historically black colleges and universities within which they most often worked as devised by the powerful and corporately connected leaders of American philanthropy. As such, the final product is an exemplary compendium of social scientific writing on race to the late 1930s. Completed during World War II, An American Dilemma (Ellison 1964) provided a megaphone through which the conflict between the American creed of egalitarian democracy and the equally public and systematic practice of racial segregation could be broadcast to the nation and the world. Furthermore, Myrdal 2006 (originally published in 1944) premiered what would be a key theme of the Cold War: the strategic necessity and moral imperative that the United States transform itself into a model democracy. It is important to note here that Myrdal was acting here as a popularizer of wisdom that, though it was not yet conventional, served as a theme that African American intellectuals in particular had been developing for many years (DuBois 2008, Logan 2001). An American Dilemma symbolized liberal "social engineering" for those who supported such interventions as well as for those who vehemently opposed them. Most important in reflecting and confirming this symbolic status was the Supreme Court's citation of it in the footnotes of its first school desegregation decision (Southern 1987). The review of Myrdal's work by Ralph Ellison scores Myrdal for continuing the American focus on the "Negro" as a problem and a victim instead of analyzing what these Americans created from adversity (Ellison 1964).

\section{Du Bois, W. E. B. “Forethought.” In The Souls of Black Folk. E-book 408. Project Gutenberg, 2008.}

In this essential collection of essays, DuBois contributes one of the most quoted observations in American letters: that "the problem of the twentieth century is the problem of the color line" (p. 13). Originally published in 1903.

\section{Ellison, Ralph. An American Dilemma: A Review, 1964.}

This review was written by Ellison for the Antioch Review, but not published until 1964, when it appeared as the last chapter of his first collection of essays, Shadow and Act (new York: Random House, 1964). The essay is noteworthy for its discussion of Robert Park and for Ellison's contention that Myrdal's endeavor constitutes part of a larger ideological effort to bring the South into modern industrial capitalism. 
Jackson, Walter A. Gunnar Myrdal and America's Conscience: Social Engineering and Racial Liberalism, 1938-1987. Chapel Hill: University of North Carolina Press, 1994.

This intellectual history is the authoritative history of how An American Dilemma came into being.

Logan, Rayford W., ed. What the Negro Wants. Notre Dame, IN: Notre Dame University Press, 2001.

This collection of essays, first published very grudgingly by the University of North Carolina Press in 1944, contains essays by the leading African American intellectuals of the era, arguing for the need to end the nation's separate and unequal system of racial segregation. The introduction by Kenneth Janken is indispensable.

Myrdal, Gunnar. An American Dilemma: The Negro Problem and Modern Democracy. New Brunswick, NJ: Transaction, 2006.

First published as two volumes in 1944, this book summarizes the state of American knowledge on its system of "race relations." The historical importance of this volume resides in Myrdal's insistence that the contradiction between the "American creed" and the American practice of discrimination can and should be ended. The full text can be downloaded online.

\section{Southern, David W. Gunnar Myrdal in Black-White Relations: The Use and Abuse of an American Dilemma, 1944-1969. Baton Rouge: Louisiana State University Press, 1987.}

Although this study discusses the creation of An American Dilemma, it is primarily a study of the symbolic career of this book through American culture: how a book titled An American Dilemma came to be remembered as "the American Dilemma."

Watkins, William H. The White Architects of Black Education: Ideology and Power in America, 1865-1954. Foreword by Robin D. G. Kelley. New York: Teachers College Press, 2001.

A rigorous analysis of the attitudes of the American philanthropists who shaped the terms by which African American education would be supported by members of the nation's industrial elite.

\section{The Age of Brown v. Board of Education}

When historians speak of a long Civil Rights movement, they are paying tribute, whether they realize it or not, to the work of journalist and historian Richard Kluger. First published in 1975, Kluger's account has become the established narrative of how, over a sixty-year period, the nation's legal establishment was pushed to overturn the doctrine of "separate but equal," with only the first part of that phrase ever being fully followed. So much of what is now summarized elsewhere was first set out by Kluger-the effort of parents in Clarendon County, South Carolina, to get one school bus, the intervention of the National Association for the Advancement of Colored People (NAACP) and the recruitment of social scientists in support of overruling "separate but equal" (Kluger 2004). Patterson 2010 provides a survey of the trials of implementation. Of all of the author's conclusions, the most important one may have been that which concerned what white Americans learned. By the late 1960s, a decade and a half of conflict over racial equality had caused many Americans to reconsider what they thought they had understood about African Americans: the Americans they saw on their television screens did not seem to self-doubting or to accept the status of second-class citizenship. Had the experts missed something? Had the mask imposed by the rules of behavior in this segregated society obscured a deeper reality of African American perceptions and resentments (Patterson 2010)? Douglas 1994, a two-volume collection dealing with the debate over what came to be known as "court-ordered busing," is instructive in demonstrating the depth and width of the divide between blacks and whites over busing. What all sides understood but could not resolve was a question as old as the republic: in this society, prized resources were held by whites. How was such a redistribution of powers and resources to be achieved in a one-way plan in which historically black schools and teachers were discarded? Douglas 2005 aids the discussion in providing a fine account of racial segregation in the North. Clotfelter 2004 provides an excellent account of how white fears of blacks affect not only school desegregation, but also housing prices and residential patterns. 
Clotfelter, Charles T. After Brown: The Rise and Retreat of School Desegregation. Princeton, NJ: Princeton University Press, 2004. Clotfelter argues that while day-to-day contact between whites and blacks has increased dramatically as a result of the reforms brought by the Civil Rights movement, African Americans and whites otherwise are more segregated than ever before.

\section{Douglas, Davison. Jim Crow Moves North: The Battle over Northern School Segregation, 1865-1954. New York: Cambridge University Press, 2005.}

The fact that Douglas surveys segregation in the North from the Civil War to Brown is, in and of itself, a major contribution. Segregation in housing in the North was even more rigid than in the South.

Douglas, Davison, ed. School Busing: Constitutional and Political Developments. 2 vols. New York: Garland, 1994.

Whether the document is a court opinion, newspaper editorial, academic article, or presidential statement on this key issue of the 1970s, the debate over busing is fully represented here.

\section{Kluger, Richard. Simple Justice: The History of Brown v. Board of Education and Black America's Struggle for Equality. Rev. ed.} New York: Alfred A. Knopf, 2004.

Provides a masterful historical account organized around vivid stories about people working at every level of society to overturn the doctrine of "separate but equal."

Martin, Waldo E., ed. Brown v. Board of Education: A Brief History with Documents. New York: Bedford/ St. Martin's, 1998. A collection of documents aimed at those who are not lawyers.

\section{Patterson, James T. Brown v. Board of Education: A Civil Rights Milestone and Its Troubled Legacy. New York: Oxford University Press, 2010.}

Patterson picks up the narrative where Kluger 2004 ends and offers a succinct survey of what the fate of Brown v. Board tells us about the last fifty years of US history.

\section{Patterns of Implementation}

Ten years after the Supreme Court had laid out a broad road map for implementing school desegregation, 99 percent of African American students in public school attended schools that were overwhelmingly black. After the Supreme Court intervened more forcefully in the late 1960s and early 1970s, this figure declined to 44 percent. At this crucial moment, Marian Wright Edelman, a leading advocate for school desegregation, found an absence of leadership from the White House on down to press forward. Instead, a politics of backlash punctuated progress in a reenactment of politics from the early 1960s. As she looked back from 1973 to the framing of the Civil Rights Act of 1964, she reminded her readers that the congressional debates surrounding what became the Civil Rights Act of 1964 drove one point home: from every region of the country, members of Congress, regardless of party affiliation, did not favor any action that would disturb the sanctity of the "neighborhood school." Republican or Democrat, from the North or the South, none would favor any federal mandate to alter school attendance patterns in the name of achieving some significant degree of racial balance. At the local level, most school boards did not exercise their "local option" to do this (Edelman 1973, p. 33). Political historians and legal historians agree that a decision that continues to be venerated as a transformative moment in American law was actually framed by very conservative values. Freyer 2007 notes that by giving oversight of judicial orders to desegregate to district court judges, the direction of change was placed, generally speaking, in very conservative and politically sensitive hands. As desegregation through court order progressed in the 1970s and 1980s several patterns emerge that cross regional boundaries. Whether it is journalist Anthony Lukacs or Ronald Formisano, 
who each examine Boston (Formisano 1991, Lukas 1986)) or work by Davison Douglas and Stephen Samuel Smith on Charlotte, North Carolina (Douglas 1995, Smith 2004)), historians have found that white elites were able to opt out of busing (sometimes because their schools were zoned out of desegregation plans, leaving the social experimentation to those families—white and black—who had no other alternative than attending the public school). The support for desegregation among the business community was fundamentally pragmatic: wishing both to project a civic image of enlightenment and to avoid an "ugly scene." The community studies of Cecelski 1994 and Shircliffe 2006 each note that desegregation was a "one way" process focused exclusively on keeping white families in the public school system, with little or no thought given to what role historically black schools and their personnel might play in a more mutually designed process of desegregation.

Cecelski, David S. Along Freedom Road: Hyde County, North Carolina, and the Fate of Black Schools in the South. Chapel Hill: University of North Carolina Press, 1994.

This was one of the first monographs to examine what was lost in terms of experience, talent, and tradition in a desegregation process that led to the closing of historically black schools and the demotion or laying off of their teachers and administrators.

\section{Douglas, Davison M. Reading, Writing and Race: The Desegregation of the Charlotte Schools. Chapel Hill: University of North Carolina Press, 1995.}

In this essential study, Douglas is among the first authors to see how class interests and business interests shaped the desegregation process. Davison also notes that, despite political turbulence, achievement gaps narrowed between black and white children.

\section{Edelman, Marian Wright. "Southern School Desegregation, 1954-1973: A Judicial-Political Overview." ANNALS of the American Academy of Political and Social Science 407 (May 1973): 32-42.}

Edelman argues that the long-term prognosis for desegregation was imperiled by a lack of affirmative leadership from the Nixon administration. In view of the rise of busing as a political issue, Edelman's discussion of resistance to it among Democrats in the North going back to the early 1960 s is fascinating. Also available from JSTOR online for purchase.

Formisano, Ronald P. Boston against Busing: Race, Class and Ethnicity in the 1960s and 1970s. Chapel Hill: University of North Carolina Press, 1991.

Formisano provides an especially perceptive analysis of how the opponents of busing were inspired in their tactics and ideology by the Civil Rights movement.

Freyer, Tony. Little Rock on Trial: Cooper v. Aaron and School Desegregation. Lawrence: University Press of Kansas, 2007.

In this case study Freyer convincingly shows that "inconsistent enforcement" and "indeterminacy" in compliance are deeply rooted in the politics of American federalism. Freyer credits President Eisenhower with suggesting to the Supreme Court that enforcement be entrusted to federal district courts.

Lukas, J. Anthony. Common Ground: A Turbulent Decade in the Lives of Three American Families. New York: Vintage, 1986. In this moving book, journalist J. Anthony Lukas does for the experience of busing in Boston what his colleague Richard Kluger did for Brown v. Board of Education in Kluger 2004 (cited under the Age of Brown v. Board of Education): telling a complex historical narrative in terms of key individual lives. 
This monograph provides a study of opposition and grudging compliance to desegregation in Florida, with a special emphasis on how racial isolation increased and black schools were redesigned into "magnets" to keep upper-middle-class whites in the Miami/Dade schools.

Smith, Stephen Samuel. Boom for Whom? Education, Desegregation and Development in Charlotte. Albany: State University of New York Press, 2004.

Smith is especially important for showing the way in which efforts were undertaken to exclude upper-class white students from the long bus rides required of blacks and whites who actually participated in desegregation.

\section{Reconsiderations in the Aftermath of Brown}

What was the impact of race on education? For the framers of the legal strategy behind Brown $v$. Board of Education, the answer was that black children were provided with a far lower quality of education than their white counterparts, even if, in the rural South, white students were getting far less education than their counterparts in other regions of the country. Without in any way disparaging the quality of the educational competence and commitment of black teachers, Fairclough 2007 demonstrates that black teachers and their students received many fewer resources than whites and often had to negotiate with great deference for what little they did receive. Cross 1991 argues that Kenneth and Mamie Clark minimized the diversity of the African American experience and their pragmatic ability to play a role without internalizing it. This intentionally racist message sent by the powers that be was received and internalized by black children early in their socialization. In view of this reality, Derrick Bell and other veterans of the struggle, in looking back from 1980 , found much to fault in a strategy that, in the final analysis, seemed concerned with keeping white children and white parents happy. What would have happened if educational experts, including the black educators who had lived under the former system, had been asked about what black children coming out of such a harmful system actually needed in order to learn and succeed in a social order that needed to change (Bell 1980, Bell 2004)? Brown-Nagin 2011 finds that the national leaders of the NAACP were too quick to dismiss the reservations held by educators and others about dismantling the dual school system in Atlanta. Although the Supreme Court has all but ended its support for school desegregation as traditionally understood, Minow 2010 urges us to look toward the values and precedents of that litigation as society today responds to the challenges of new groups seeking this first right of American citizenship.

\section{Bell, Derrick. Silent Covenants: Brown v. Board and the Unfulfilled Hopes for Racial Reform. New York: Oxford University Press,} 2004.

Bell argues that, rather than focusing on the educational needs of black children, the architects of this litigation placed a special value on bringing black and white children together, suggesting that "black" schools were inferior because of the absence of whites.

Bell, Derrick, ed. Shades of Brown: New Perspectives on School Desegregation. New York: Teachers College Press, 1980. This volume brings together essays by young scholar activists who cut their teeth in the struggle to desegregate American public education. While desegregation remains their goal, they each conclude that they and other advocates misjudged the depth of white resistance.

\section{Brown-Nagin, Tomiko. The Courage to Dissent: Atlanta and the Long History of the Civil Rights Movement. New York: Oxford University Press, 2011.}

The author argues that the NAACP erred in not listening more closely to African American educators and other local people who feared the loss of historically black schools.

Clark, Kenneth B. Prejudice and Your Child. Foreword by Stuart W. Cook. 2d rev. ed. Middletown, CT: Wesleyan University Press, 1988. 
In this edition, Clark discusses the many versions of the "doll study" research that he and his wife, Dr. Mamie Clark, conducted. This book is also useful for Clark's discussion of how segregation also psychologically harms those who benefit from it.

\section{Cross, William E., Jr. Shades of Black: Diversity in African-American Identity. Philadelphia: Temple University Press, 1991}

The most important critique of Clark 1988 from within social science. Among many important arguments, Cross contends that the Clarks interpreted children's responses too literally without taking into account the children's desire to give an authority figure the answer dictated by the cultural etiquette of segregation.

\section{Fairclough, Adam. A Class of Their Own: Black Teachers in the Segregated South. Cambridge, MA: Belknap, 2007.}

Fairclough is especially adept at reconstructing the kinds of negotiations and understandings within which black educators had to work. $\mathrm{He}$ also nicely elucidates the genuine concerns of black educators, which the NAACP sometimes dismissed as expressions of narrow self-interest.

\section{Minow, Martha. In Brown's Wake: Legacies of America's Educational Landmark. New York: Oxford University Press, 2010.}

Minow has special appreciation for Brown as an educational landmark. Of special interest are her essays on the implication of Brown for this country's indigenous people and those who are disabled. Minow is one of the only scholars to address the impact of Brown abroad (Northern Ireland).

\section{Scott, Daryl Michael. Contempt and Pity: Social Policy and the Image of the Damaged Black Psyche. Chapel Hill: University of} North Carolina Press, 1997.

Scott situates the civil rights discourse on racial discrimination in relation to a neo-conservativism that embraces "damage imagery" to argue against further social reform.

\section{The Persisting Force Field}

The Civil Rights movement succeeded in removing some important legal and institutional barriers to African American participation in American life; as result, according to Keppel 1995, a new national iconography emerged in which African American figures were taken as representatives of the national identity not because they had somehow "transcended" their racial identity but because their struggle to be recognized as quintessential Americans transcended the force field of white racism. Progress in the decades after the enactment of civil rights legislation was quite real. According to Pattillo-McCoy 1999, the numbers of African Americans categorized by the census bureau as "middle class" continued to grow: between 1980 and 1995, the black middle class grew from just over 1.3 million to nearly 7 million. The research in Feagan and Sikes 1994 demonstrates that progress came at the cost of having to confront white resistance as a recurring part of daily life. Indeed, the psychic costs of these encounters became the basis for influential biographically informed essays by Cornel West and Patricia J. Williams, suggesting that African Americans, at every level of society, needed the protection of the "double consciousness" first expressed in DuBois's concept of "double consciousness" (West 1993, Williams 1991). The persistence of inequality engendered an important debate. If some social scientists, such as Joyce Ladner and colleagues, believed it was time to stop thinking about black lives solely in terms of how they compared to white norms (Ladner 1998), other scholars, such as Thomas Sowell, feared the consequences of such a conceptual overhaul, especially in a society in which debates were still anchored around trying to explain and eliminate racial disparities in many areas of social life. Though Sowell 2013 agreed that "race" was a social construct and that looking for genetic explanations for aggregate differences between groups had no scientific basis, did not cultural difference within the black community cause some to be unable to reach out to grasp the opportunities of American society?

Feagan, Joe R., and Melvin P. Sikes. Living with Racism: The Black Middle-Class Experience. Boston: Beacon, 1994. 
Feagan and Sikes provide abundant evidence here in stating: "Today, blatant, subtle, and covert discrimination against AfricanAmericans persists in virtually all aspects of their public lives. Racism is central in the lives of white Americans, too, even though many whites deny its presence or effects" (p. 319).

Keppel, Ben. The Work of Democracy: Ralph Bunche, Kenneth B. Clark, Lorraine Hansberry and the Cultural Politics of Race. Cambridge, MA: Harvard University Press, 1995.

This monograph examines how three key African American icons of the postwar years sought to use their status as national symbols to further advance American understandings about race. In each case, iconic status proved to be both confining and liberating for the individuals involved.

\section{Ladner, Joyce A. Tomorrow's Tomorrow: The Black Woman. Lincoln: University of Nebraska Press, 1995.}

Ladner speaks frankly about how the Civil Rights movement shaped her approach to social science. In particular, she argues that understanding the African American experience has been hindered by the tendency by scholars of all races to think about African American life only as it approximates or deviates from alleged white norms. Includes a new introduction by the author.

Ladner, Joyce A., ed. The Death of White Sociology. Baltimore: Black Classic Press, 1998.

Originally published in 1973. This is the single most important collection of essays to suggest the lessons to be learned from the Civil Rights movement by mainstream social scientists.

Pattillo-McCoy, Mary. Black Picket Fences: Privilege among the Black Middle Class. Chicago: University of Chicago Press, 1999. The author finds that the black middle class must live in far more demographically cramped conditions because of continuing white resistance. Pattillo-McCoy also challenges the social scientific and popular tendency to compare black lives (or white lives) against the imagined yet unexamined norms ascribed to the white middle class.

Sowell, Thomas. Intellectuals and Race. New York: Basic Books, 2013.

Sowell summarizes arguments made in earlier monographs on ethnicity and race. He argues that the liberal establishment in American social science and the media is unwilling to explore the possibility that some racial disparities originate in forces that are internal to the African American community rather than stemming from external racism.

\section{West, Cornel. Race Matters. Boston: Beacon, 1993.}

Written in the aftermath of the Rodney King riots in the spring of 1992 (and first published as essays in the New York Times Magazine), this volume established West as a major public intellectual. West uses his inability to hail a cab in New York City as the launching point for a meditation on the American politics of race.

Williams, Patricia J. The Alchemy of Race and Rights. Cambridge, MA: Harvard University Press, 1991.

This essay is an intellectually rigorous autobiographical meditation on how the power of certain deep cultural conventions allows certain peoples to take on the mantle of possessing transcendent "objective truth," and how this ordering of things renders the author's experience as an African American female as something else and something less. 


\section{The African American Citizen in Civil Society}

For W. E. B. Du Bois, the short-lived first reconstruction testified to the social democratic aspirations of newly freed African Americans (Du Bois 2013). In the 1970s, Holt 1979 returned to this subject and cast considerable doubt on Du Bois's contention that African American politicians had attempted a proletarian revolution during their brief ascendency in politics in the South. Holt found that the free blacks (many of whom had been small-scale commercial farmers) voted their class interests on issues such as debt peonage. Moving forward, Guinier 1994 sees a reenactment of old patterns. Since passage of the Voting Rights Act in 1965, racial polarization has been perhaps the most stable feature of American politics. Especially in the South, the white political establishment (Republican and Democratic) worked hard to dilute the electoral impact of black voters on policy, which requires us to rethink the assumptions we bring to what constitutes political "fair play." Outside the South, Dianne Pinderhughes's study of Chicago politics convincingly disproves the thesis that African American political progress can be effectively mapped onto a theory of pluralism developed to explain the integration of white ethnics into the American political system (Pinderhughes 1987, Pinderhughes 2009). And in these circumstances, Walters 1988 argues that a shared policy-based perception of discrimination can be mobilized to change the national balance of power. However, the same social and economic forces that are creating greater class stratification between African Americans pose a serious challenge to politics as traditionally practiced by African Americans. Cohen 1999 argues that this trend may have the political consequence of undermining the solidarity created by a perception widely held by African Americans that they share a "linked fate" grounded in a shared history of oppression. Furthermore, as visually and emotionally compelling as the pageantry and rhetoric of a "charismatic politics" looking back to the civil rights years may be, Reed 1986 argues that this cannot keep us from keeping an eye on those things, more hidden, that African American politics and politicians share with politics and politicians, namely, the coalitions with business interests that help keep old structural patterns in place.

Cohen, Cathy J. Boundaries of Blackness: AIDS and the Breakdown of Black Politics. Chicago: University of Chicago Press, 1999. Cohen argues that past social and political solidarity among African Americans in service to a broadly social democratic agenda will end if economic and social stratifications are allowed to make it easier to cast certain African Americans (those who are gay, poor, or use drugs) as outside the circle of community concern.

\section{Du Bois, W. E. B. Black Reconstruction in America: Toward a History of the Part Which Black Folk Played in the Attempt to Reconstruct Democracy in America, 1860-1880. New Brunswick, NJ: Transaction, 2013.}

Originally published in 1935. Du Bois argues that the black political leaders who gained some measure of power in the South under the protection of federal troops sought a social democratic revolution. This book was rediscovered by scholars in the 1960 s and, inspired by Du Bois's provocative arguments, they produced detailed studies of African Americans as sophisticated historical actors during the period of Reconstruction. Includes a new introduction by Mark H. Jones.

Guinier, Lani. Tyranny of the Majority: Fundamental Fairness in Representative Democracy. New York: Free Press, 1994.

Guinier advocates "cumulative voting" and formulas leading to greater proportionality in electoral outcomes, encouraging a coalition politics based on political interests rather than race. These essays led her to be nominated to serve in the Clinton administration to head the Civil Rights Division, a nomination that was subsequently withdrawn.

Holt, Thomas. Black over White: Black Political Leadership in South Carolina during Reconstruction. Urbana: University of Illinois Press, 1979.

Drawing upon extensive archival research and utilizing sophisticated statistical techniques, Holt finds that most of the black men who entered politics at this time were not former slaves but free blacks with entrepreneurial interests who voted their economic interests when it came to issues such as debt peonage. 
Illinois Press, 1987.

This study of the integration of African Americans into Chicago politics between 1931 and the election of Harold Washington as mayor in 1983 argues against the tendency of political scientists to apply to black politics models constructed to describe the political integration of Poles, Italians, and other white ethnic groups.

Pinderhughes, Dianne M. "Presidential Address: The Challenge of Democracy: Explorations in American Racial Politics." Perspectives on Politics 7.1 (March 2009): 3-11.

Pinderhughes intertwines her own life experience with a discussion of the difficulty political scientists have had addressing the African American experience; she also discusses notable new work that points toward progress on this front. This address was given to mark the end of her term as president of the American Political Science Association (2007-2008).

\section{Reed, Adolph L. The Jesse Jackson Phenomenon: The Crisis of Purpose in Afro-American Politics. New Haven, CT: Yale University Press, 1986.}

In this essay, Reed challenges the assumption that the presidential candidacy of Jesse Jackson galvanized voters; according to this analysis, the policies of Ronald Reagan were the primary cause, with Jesse Jackson being the beneficiary.

Walters, Ronald. Black Presidential Politics in America: A Strategic Approach. Albany: State University of New York Press, 1988. Walters, a key adviser to Jackson's 1984 campaign, answers Reed 1986.

\section{The City as Sociological Subject and Political Site}

The city has been a rich subject for social investigation. For American social investigators the city, especially Chicago, has been an important laboratory for studying race relations (see the Chicago School as the First Capital of American Social Science). W. E. B. Du Bois pioneered this line of inquiry with respect to African Americans. He was the first person to propose that the slave past continued to act upon social relations between African Americans and the rest of society. He was also the first to argue that this particular history meant that African Americans faced a far more difficult struggle for upward mobility than white immigrants. Finally, he suggested that differences between working-class African Americans (who were the vast majority within this particular group) and others could best be explained through cultural differences rather than inferior genetics (Du Bois 2014, originally published in 1899). Investigators working within the framework of the Chicago School continued to develop the argument that history had rendered African Americans different from other Americans (see Model Studies from within the Chicago School). After World War II, New York, especially Harlem, became an important national setting from which African American intellectuals across disciplines debated the nation's social, political, and cultural destiny through the medium of the struggles of African Americans, who, through the course of the 20th century, had migrated to northern cities. In this setting, psychologist Kenneth Clark has a special significance. As a onetime resident of Harlem, his Northside Center for Child Development served its people (Matlin 2013). As Keppel 1995 and Keppel 2002 argue, Clark's study of Harlem, Dark Ghetto, confirmed his status as a participant symbol in the changing relationship of African Americans to the rest of society. In this book, Clark both challenged and confirmed a disciplinary tendency to approach working-class African American life as deviant. He also conceived of racial ghettos as prisons constructed to facilitate a type of internal colonialism (Clark 1989). In the aftermath of the Rodney King riots, the authors of Bobo, et al. 2000 led an effort to examine Los Angeles as a "prismatic metropolis" within which immigration played a unique role. Bobo and his colleagues found a continuing pattern of racial subordination that not only separated African Americans from whites, but also separated immigrants and African Americans from whites socially and economically in established patterns of residential segregation (Bobo, et al. 2000).

Bobo, Lawrence D., Melvin L. Oliva, James H. Johnson Sr., and Abel Valenzuela Jr., eds. Prismatic Metropolis: Inequality in Los Angeles. New York: Russell Sage Foundation, 2000.

A landmark study in the "highly radicalized urban environment" of Los Angeles based on 4,025 interviews completed between 1993 and 
1994. The major finding is of a consistent pattern of residential segregation and economic inequality between blacks and Hispanics relative to whites and Asians.

Clark, Kenneth B. Dark Ghetto: Dilemmas of Social Power. 2d ed. Middletown, CT: Wesleyan University Press, 1989.

Originally published in 1965. Clark portrays Harlem as an "internal ghetto" trapped in a "tangle of pathology" and urges social science to more closely examine the resilience and strength in the people of this and other inner-city communities. Includes a new introduction by William Julius Wilson.

\section{Du Bois, W. E. B. The Philadelphia Negro: A Social Study. New York: Oxford University Press, 2014.}

Originally published in 1899. The first social science research by an African American to be recognized by the American intellectual establishment. In focusing on explaining the differences between whites and blacks in socioeconomic and cultural terms, Du Bois set out an agenda that continues to guide public debate. Includes a new introduction by Lawrence Bobo.

\section{Keppel, Ben. The Work of Democracy: Ralph Bunche, Kenneth B. Clark, Lorraine Hansberry and the Cultural Politics of Race. Cambridge, MA: Harvard University Press, 1995.}

Examines the dilemmas faced by African American public figures seeking to lead American thinking about African Americans and the concept of race in new directions.

\section{Keppel, Ben. "Kenneth Clark in the Patterns of American Culture." American Psychologist 57.1 (2002): 29-37.}

This essay considers Kenneth Clark's contribution to American public discourse with a special emphasis on the years after Brown $v$. Board.

\section{Matlin, Daniel. On the Corner: African-American Intellectuals and the Urban Crisis. Cambridge, MA: Harvard University Press,} 2013.

The excellent collection of intellectual portraits extend and deepen our understanding of the public discourse on race and the city during the 1960s, including why black men constituted such exclusive symbols in this debate.

\section{Debating Race and Culture in the American City}

The report by Daniel Patrick Moynihan in 1965 reintroduced E. Franklin Frazier's thesis that the structure of the black family had been harmed in the long term by the continuation of social relations imbedded in the slave past (Moynihan 1965; also see Frazier 1966, cited under Model Studies from within the Chicago School). The collection of documents and the analysis in Rainwater and Yancey 1967 demonstrate that, by 1966, these findings were unexpectedly controversial. Some social scientists and some civil rights leaders believed that Moynihan was, perhaps unwittingly, contributing to the creation of a new social context in which continuing black "deviance" rather than persistent racism would be the culprit (Rainwater and Yancey 1967). Nonetheless, a decade after the Moynihan debate broke out, the author of Wilson 1978 argued that the formal desegregation of national institutions had made race a less important factor in the nation's life than it had been previously. Many African Americans, who were not immediately prepared by education and social background to avail themselves of the new opportunities, were being held back. Wilson 2012 goes on to posit that the long-term impact of the Moynihan debate has had deeply damaging effects on the debate over public policy. Because social scientists were now less willing to either investigate or debate the existence of an "underclass" among some African American communities, the social conditions of African Americans outside of an expanding black middle class was growing worse and, indeed, was hardening into a permanent "underclass" (Wilson 1996). Wilson has often been grouped in these debates with Glenn Loury and Orlando Patterson, to whom some have assigned the label "black conservatives." Unlike some conservatives in the American intellectual and political establishment, 
neither Loury nor Patterson denies the persistence of racism as a continuing and heavy cultural and institutional factor in American life. Along with Wilson, whose policy recommendations for government intervention are far from conservative, Loury 2005 and Patterson 2015 insist that special attention must be given to an equally persistent culture among working-class and middle-class African Americans that makes them unable to rise to the degree of their aspirations. The debate over Wilson's legacy continues, as is evident in the pages of Ethnic and Racial Studies (Young 2003).

Loury, Glenn C. "Race, Inequality, and Justice in the U.S.A: Some Social-Philosophic Reflections." In Ethnicity, Social Mobility, and Public Policy: Comparing the U.S. and the U.K. Edited by Glenn C. Loury, Tariq Modood, and Steven M. Teles, 571-601. New York: Cambridge University Press, 2005.

Loury provides an incisive critique of classical liberalism's emphasis on individualism, which ignores the existence of racism and its collective through its institutionalization in social and political processes of the market and the state. These forces have helped create a culture that, independent of material circumstances, leaves some African Americans without essential tools to escape poverty and racial isolation.

Moynihan, Daniel Patrick. The Negro Family: The Case for National Action. Washington, DC: US Department of Labor, 1965. This government report, written by Daniel Patrick Moynihan and released in the spring of 1965, uses E. Franklin Frazier's The Negro Family in America (Frazier 1966, cited under Model Studies from within the Chicago School) to argue that the African American remains culturally handicapped by the legacy of discrimination originating in slavery.

Patterson, Orlando. "The Social and Cultural Matrix of Black Youth." In The Cultural Matrix: Understanding Black Youth. Edited by Orlando Patterson, 45-135. Cambridge, MA: Harvard University Press, 2015.

Patterson reviews the sociological literature on black youth in American culture. He argues that black youth of both "middle class" and "proletarian" backgrounds understand and support the "mainstream" value of individual responsibility, but that the immediately surrounding culture can be a barrier to the full attainment of this aspiration.

Rainwater, Lee, and William L. Yancey. The Moynihan Report and the Politics of Controversy. Cambridge, MA: MIT, 1967. Testifying to the continuing relevance of the Moynihan Report, this compendium of documents capturing the early debate has never been out of print for nearly fifty years.

Wilson, William Julius. The Declining Significance of Race: Blacks and Changing American Institutions. Chicago: University of Chicago Press, 1978.

This extremely influential book argues that, even as the formal and official structures of racial discrimination fall, attention must remain on the differential impact that they have left on economic relations.

Wilson, William Julius. When Work Disappears: The World of New Urban Poor. New York: Vintage, 1996.

Here Wilson quite deliberately brings to mind the earlier studies of the racial and ethnic ecology of Chicago pioneered by St. Claire Drake and Horace Cayton Jr. in Negro Metropolis (see Drake and Cayton 1945, cited under Model Studies from within the Chicago School) as he describes the consequences of the migration of economic and human capital from the central city.

Wilson, William Julius. The Truly Disadvantaged: The Inner City, the Underclass, and Public Policy. 2d ed. Chicago: University of Chicago Press, 2012. 
Wilson revisits the debate over the Moynihan Report and its sad consequences for social science and public policy.

Young, Alford, Jr., ed. Special Issue: The Contribution of William Julius Wilson. Ethnic and Racial Studies 26.6 (2003).

This special issue offers five assessments of Wilson's intellectual contribution, with a rejoinder from Wilson himself. In addition, Reuben A. Buford May offers an appreciation of Wilson as a mentor. Available online by subscription or for purchase.

\section{The Costs and Consequences of Mass Incarceration}

The roots of the current regime of mass incarceration are, Alexander 2012 posits, deeply historical and yet they have been activated and strengthened in the 1980s and 1980s by a shift in public opinion back toward viewing African Americans as deviant. Patterson 2015 fears that Alexander and her allies have overemphasized the capacities of many offenders and overstated what is lost when a family member is incarcerated. In the current environment, the childhoods of poor black and Latinos are comprehensively "criminalized" even if the youth has broken no law. Victor M. Rios's ethnography of coming of age in the "flatlands" of Oakland, California, finds that their environment impedes these youth from acquiring the kinds of skills needed to succeed within the law. Even those luck few who are able to succeed in both the neighborhood and school are made to feel like an outsider in both places (Rios 2012). Clear 2007 and Loury 2008 agree that no one has been made safer by a short-term and politically expedient crime control strategy. Leading scholars, in works such as Western, et al. 2004, have documented the ways this "solution" has made weak families even weaker. Although there is no cureall, the evidence suggests that incarcerating violent offenders and those who commit crimes against property does lessen crime, even if defining who belongs in this category is more difficult than many people realize. Mary D. Looman and John D. Carl have a great deal of company when they propose using prison time to build up the human capital of the offender, which often also means treating mental illness for the first time (Looman and Carl 2015, Clear 2007, Loury 2008, Useem and Piehl 2008, Rios 2012).

Alexander, Michelle. The New Jim Crow: Mass Incarceration in the Age of Color-Blindness. 2d ed. New York: New Press, 2012. The first edition is available for reading online. The second edition is available through ProQuest online by subscription. Alexander's particular interest here is the way in which, after the advances of the Civil Rights movement and the so-called second reconstruction of the 1960s, the Supreme Court, Congress, and some elements of the American establishment have converged on the "war on drugs" to redefine black Americans as dangerous deviants in need of containment.

Clear, Todd R. Imprisoning Communities: How Mass Incarceration Makes Disadvantaged Neighborhood Worse. New York: Oxford University Press, 2007.

This review of the literature finds wide-ranging consequences of mass incarceration: in addition to denying communities human capital, a community in which a large number of people have been incarcerated means a community with less earning power and greater political cynicism, making it harder to mobilize for constructive change.

Looman, Mary D., and John D. Carl. A Country Called Prison: Mass Incarceration and the Making of a New Nation. New York: Oxford University Press, 2015.

The United States and Russia are the only nations whose statistics rates run counter to the strong correlation between high economic wealth and low incarceration rates. Noting that the incarcerated share many deficits in common, the authors advocate that prison time should more effectively be used to develop "executive functioning" and other rehabilitative skills.

Loury, Glenn C. Race, Incarceration, and American Values. Cambridge, MA: MIT, 2008.

Loury and colleagues note that the predicted "bloodbath of juvenile homicides" that provoked tougher sentences never actually took place; nonetheless, these laws facilitated the "imposition of social exclusion" and "civic excommunication" that have marked a step 
Patterson, Orlando. "The Social and Cultural Matrix of Black Youth." In The Cultural Matrix: Understanding Black Youth. Edited by Orlando Patterson, 45-135. Cambridge, MA: Harvard University Press, 2015.

On pp. 115-116, Patterson questions Michelle Alexander's contention that mass incarceration deprives inner cities of valuable human capital.

\section{Rios, Victor M. Punished: Policing the Lives of Black and Latino Boys. New York: New York University Press, 2012.}

This study of young boys from the "flatlands" of Oakland, California, finds that they grow up in a public environment in which virtually all of their actions and conduct are seen as criminal. This environment encourages the development of skills that are misunderstood by, and are inimical to, success in the larger society.

Useem, Burt, and Anne Morrison Piehl. Prison State: The Challenge of Mass Incarceration. New York: Cambridge University Press, 2008.

The authors point out the difficulty of determining who is a "nonviolent offender" as one impediment to quick reform. They advocate a greater investment in "human capital" and warn that lowering the incarceration rate will not be easy or as "cost effective" as some believe.

Western, Bruce, Leonard M. Lopoo, and Sarah McLanahan. "Incarceration and the Bonds between Parents in Fragile Families." In Imprisoning America: The Social Effects of Mass Incarceration. Edited by Mary Patillo, David Weiman, and Bruce Western, 21-45. New York: Russell Sage Foundation, 2004.

Since marriage represents a "step away" from criminal behavior and mass incarceration weakens families, incarceration should be restricted to those who have committed violent crimes or crimes against property because removing these offenders does increase community safety. Policies that aim to "round up" drug offenders are self-defeating to long-term community and family stability.

\section{Policing the Force Field}

As the pressure on American institutions to demonstrate their allegiance to democratic principles increased, African Americans became outspoken leaders of the profession, sometimes leading to an overestimation of progress (Dulaney 1996). In addition, Samuel Walker finds that it is difficult to enforce federal directives at the local level (Walker 2005), a problem very familiar to students of school desegregation (see the Age of Brown v. Board of Education). Lawrence 2000 finds that video footage of Rodney King being beaten by police made this event into an important "news icon," which provoked a thorough discussion but considerably less reform. The most important contribution of the intervention of video technology is to add voices to the official and media narratives that previously would have been ignored or dismissed. In recent years, social scientists, including a team of researchers led by Patricia Warren, have been actively searching for ways to understand, quantify, and measure what happens to the person who is stopped "driving while black" (Warren, et al. 2006).

\section{Dulaney, W. Marvin. Black Police in America. Bloomington: Indiana University Press, 1996.}

An admirably succinct overview of its subject.

Lawrence, Regina G. Police Force. Berkeley: University of California Press, 2000.

This is a key source for understanding the significant, yet limited, impact of the King beating as a "news icon" on institutional reform in 
Los Angeles.

Walker, Samuel E. The New World of Police Accountability. Thousand Oaks, CA: SAGE, 2005.

A brief overview of the increase in police accountability because of the intervention, beginning in the 1960s, of the Supreme Court and the Department of Justice. The narrative is focused on developments since the 1990 s and notes some progress, mixed with weak local enforcement in some cases.

\section{Warren, Patricia, Donald Tomaskovic-Devey, William Smith, Matthew Zingraff, and Marcinda Mason. "Driving While Black: Bias Processes and Racial Disparity in Police Stops." Criminology 44.3 (2006): 709-738.}

Investigates traffic stops in North Carolina using the North Carolina Highway Traffic Study; suggests that the racial disparity in traffic stops reflect the fact that policing is not evenly distributed across the population. The challenges of doing such research (the absence of abundant public data on traffic stops), even in the uniquely data-rich jurisdiction of North Carolina, are discussed. Available online by subscription or for purchase.

back to top

\section{You are browsing courtesy of: Oxford University Press - Main Account}

Copyright $\odot$ 2016. All rights reserved. 